\title{
KONSELING KELOMPOK DENGAN TEKNIK CLIENT CENTERED THERAPY DALAM MENINGKATKAN KETAATAN TERHADAP TATA TERTIB SEKOLAH
}

\author{
Suerlin Setyawati \\ Program Studi Psikologi Pendidikan Islam \\ Program Pasca Sarjana Magister Studi Islam \\ Universitas Muhammadiyah Yogyakarta \\ E-mail: Suerlinsetyawati27@gmail.com
}

\begin{abstract}
Abstrak
Tujuan penelitian ini adalah untuk mengetahui pengaruh konseling kelompok dengan teknik client centered therapy terhadap peningkatan ketaatan tata tertib sekolah. Penelitian quasi eksperimental one group pretest and posttest ini mengambil sampel sebanyak 30 subjek dari siwa kelas VIII MTs Negeri 4 Sleman. Intrumen penelitian berupa seperangkat angket skala likert mengenai sikap terhadap ketaatan tata tertib sekolah. Setelah melalui uji persyaratan analisis, data dianalisis dengan uji-t dengan bantuan SPSS.10. Hasil penelitian menunjukkan bahwa ada pengaruh pemberian layanan konseling kelompok dengan teknik client centered therapy dalam meningkatkan ketaatan terhadap tata tertib sekolah, Pengaruh ini ditunjukkan oleh hasil uji-t yang menunjukkan taraf signifikansi yang tinggi yaitu 3,084. Sementara itu untuk nilai t tabel untuk $\mathrm{N}=30$ dengan taraf signifikansi 95\% hanya sebesar 0,683. Dengan demikian layanan konseling kelompok dengan teknik client centered therapy mampu meningkatkan ketaatan terhadap tata tertib sekolah.

Kata kunci: konseling kelompok, client centered therapy, ketaatan tata tertib.
\end{abstract}

\footnotetext{
Abstract

The purpose of this study is to determine the effect of group counseling with a client centered therapy techniques to increase of the obedience to the school rules. Quasiexperimental study one group pretest and posttest took a sample of 30 subjects from class VIII MTs 4 Sleman. A set of research instrument s wereLikert scale questionnaire regarding attitudes toward obedience to the school rules. After passing the test requirements analysis, data were analyzed using t-test with the help ofSPSS.10. The results showed that there is the effect of group counseling services with client centered therapy techniques to improve adherence to the school rules, The effect demonstrated by the t-test results that show a high significance level is 3.084. Meanwhile, the value of $t$ table for $N=30$ with 95\% significance level of only 0.683. Thus the group counseling services with client centered therapy techniques can increase the adherence to the school rules.
}

Keywords: group counseling, client centered therapy, the obedience of rules. 


\section{Info Artikel}

Diterima Mei 2017, disetujui Juni 2017, diterbitkan Juni 2017

PENDAHULUAN

Lingkungan sekolah yang teratur, tertib, tenang memberi gambaran lingkungan siswa yang giat, gigih, serius, dan kompetitif. Dengan demikian maka potensi yang ada pada peserta didik dapat berkembang dengan optimal. Hal ini sejalan dengan tujuan pendidikan nasional yang tertuang dalam UU. No. 20 tahun 2003 pasal 3 yang berbunyi : tujuan pendidikan nasional adalah mengembangkan potensi peserta didik agar menjadi manusia yang beriman dan bertaqwa kepada Tuhan yang maha esa, berakhlak mulia, sehat, berilmu, cakap, kreatif, mandiri.

Kenyataan yang kita jumpai, berdasarkan dokumen catatan pelanggaran tata tertib, hampir semua siswa pernah melanggar tata tertib sekolah, baik yang disengaja ataupun tidak disengaja. Bahkan sekarang ini pelanggaran terhadap tata tertib di sekolah semakin mengkhawatirkan. Mulai dari hal-hal kecil seperti: terlambat datang, tidak mengerjakan PR, berpakaian tidak sepantasnya, sampai pelanggaran yang serius misalnya, membuat keonaran di lingkungan sekolah, meninggalkan sekolah pada jam effekif tanpa seijin sekolah, merokok di lingkungan sekolah, tawuran antar sekolah, bahkan sampai pada perbuatan asusila.

Berdasarkan data yang ada pada guru BK serta pengamatan di lapangan, menunjukkan bahwa beberapa kejadian bersifat negative yang terjadi pada siswa disebabkan karena pelanggaran terhadap tata tertib di sekolah. Untuk itu perlu upaya untuk meningkatkan ketaatan siswa terhadap tata tertib sekolah. Salah satu upaya yang bisa ditempuh dalam meningkatkan ketaatan terhadap tata tertib di sekolah adalah dengan memaksimalkan layanan bimbingan konseling kelompok. Karena Bimbingan kelompok merupakan cara yang efektif dan efisien untuk mendukung dan membantu siswa dalam mencegah timbulnya masalah dan memecahkan masalah-masalah di bidang perkembangan pendidikan, karier, pribadi dan sosial.

Dalam pelaksanaan pemberian bimbingan dan konseling kelompok untuk meningkatkan ketaatan terhadap tata tertib, lebih efisien dan efektif bila menggunakan bimbingan konseling kelompok, karena dengan sekali bimbingan konseling kelompok bisa menangani beberapa siswa. Dalam bimbingan konseling ada beberapa tehnik yang bisa di gunakan, salah satu tehniknya adalah client centered therapy.

Menurut Prayitno dan Erman Amti client centered theraphy adalah klien diberi kesempatan mengemukakan persoalan, perasaan dan pikiran- pikirannya secara bebas. Pendekatan ini juga mengatakan 
bahwa seseorang yang mempunyai masalah pada dasarnya tetap memiliki potensi dan mampu mengatasi masalahnya sendiri. Jadi client centered therapy adalah terapi yang berpusat pada diri client, yang mana seorang konselor hanya memberikan terapi serta mengawasi klien pada saat mendapatkan pemberian terapi tersebut agar klien dapat berkembang atau keluar dari masalah yang dihadapinya.

Dengan penerapan model konseling kelompok dengan teknik client centered therapy untuk meningkatkan ketaatan terhadap tata tertib sekolah, dapat mengatasi kendala-kendala dan kekurangan bimbingan konseling konvensional, karena model layanan bimbingan konseling kelompok dapat mengevisienkan waktu layanan. Selain itu siswa dapat lebih mudah meningkatkan ketaatan terhadap tata tertib sekolah, karena model ini memberikan kesempatan kepada siswa untuk sungguh-sungguh didengar dan mendengar, sehingga mereka bisa menjadi diri sendidri, sebab mereke tahu bahwa mereka tidak akan dievaluasi dan dihakimi dan klien bebas bereksperimen dengan tingkah laku yang baru, sehingga diharapkan klien memikul tanggung jawab atas diri mereka sendiri.

Bertolak dari hal-hal di atas, maka penelitian ini hendak menguji landasan teori tentang Efektivitas Layanan Bimbingan Konseling Kelompok dengan Teknik Client
Centered Therapy terhadap Ketaatan Tata Tertib Sekolah. Untuk itu penelitian ini sangat penting untuk dilakukan.

Penelitian ini sengaja hanya dilakukan di MTs Negeri Sleman Kota, dengan pertimbangan penelitian ini membutuhkan observasi yang ketat dan observasi dilakukan setiap hari, sejak siswa datang sampai siswa pulang selama penelitian berlangsung, hal ini dilakukan agar diperoleh hasil yang akurat dan peneliti bisa terjun langsung dalam observasi setiap harinya.

\section{METODE PENELITIAN}

Penelitian ini merupakan penelitian mixed method (campuran), yaitu penelitian kuantitatif dan kwalitatif. Penelitian kuantitatif dengan menggunakan kuasi eksperimen (quasi eksperimental design). Metode ini digunakan untuk menguji coba suatu metode pembelajaran dengan sengaja membangkitkan timbulnya suatu kejadian, kemudian diteliti bagaimana akibatnya. Dalam penelitian ini disiapkan skala sikap untuk mengukur perbedaan antara sebelum diberi layanan bimbingan konseling kelompok dengan teknik Client Centered Therapy dengan sesudah diberi layanan bimbingan konseling kelompok dengan 
teknik Client Centered Therapy.

Penelitian kualitatif dilakukan dengan cara observasi. Observasi dilakukan sebelum dan sesudah layanan bimbingan konseling kelompok dengan teknik client centered theraphy, hal ini dilakukan untuk memperkuat hasil penelitian.

Penelitian ini dilakukan untuk mencari pengaruh sebelum layanan bimbingan konseling kelompok dengan teknik client centered terapi dengan sesudah layanan bimbingan konseling kelompok dengan teknik client centered therapy.

Desain penelitian yang digunakan adalah one sample pretest and posttest design. Di dalam desain ini, tes dilakukan 2 kali yaitu sebelum pelaksanaan eksperimen (pre test) dan sesudah pelaksanaan eksperimen (post test). Pola pre test and post test design dapat digambarkan sebagai berikut: $\mathrm{O}_{1}$ dan $\mathrm{O}_{2}$ merupakan hasil layanan sebelum dan sesudah layanan bimbingan konseling kelompok dengan teknik Client Centered Therapy. Formulasi tersebut dikaitkan dengan obyek penelitian dan tema penelitian dapat dirumuskan sebagai berikut:

Tabel 1. Desain Penelitian

\begin{tabular}{|l|l|l|l|}
\hline Grup & $\begin{array}{l}\text { Pre } \\
\text { Test }\end{array}$ & $\begin{array}{l}\text { Layana } \\
\mathrm{n}\end{array}$ & $\begin{array}{l}\text { Post } \\
\text { Test }\end{array}$ \\
\hline $\begin{array}{l}\text { Eksperime } \\
\mathrm{n}\end{array}$ & $\mathrm{O}_{1}$ & $\mathrm{X}_{1}$ & $\mathrm{O}_{2}$ \\
\hline
\end{tabular}

KETERANGAN:

O1 :Pre test

O2 :Post test

X1 :Layanan konseling kelompok dengan teknik Client Centered Therapy

Tempat

penelitian mengambil lokasi di Madrasah Tsanawiyah Negeri Sleman Kota. Alasan akademik pemilihan tempat penelitian ini adalah: Madrasah Tsanawiyah Negeri Sleman Kota sebagai lembaga pendidikan negeri terakreditasi A, prestasi akademk tahun 2015 peraih nilai UN tertinggi MTs seKabupaten Sleman, lulusannya ada yang diterima di SMU 1 TELADAN YOGYAKARTA, SMA Taruna Nusantara, MAN Insan Cendekia dan sekolah favorit lainnya. Prestasi non akademik juga banyak diperoleh siswa MTs Negeri Sleman Kota, mulai dari tingkat kabupaten sampai tingkat nasional. Berdasar pertimbangan tersebut Madrasah Tsanawiyah Negeri Sleman Kota ini punya posisi strategis 
eksperimen model layanan bimbingan konseling kelompok dengan tehnik client center therapy dapat dilaksanakan dengan efektif.

Waktu penelitian lebih kurang 1 bulan, dengan kegiatan antara lain: penelitian pendahuluan, pengembangan instrumen dan pelaksanaan layanan. Dalam sebuah penelitian, subyek penelitian merupakan kedudukan yang sentral, karena pada saat penelitian itulah data tentang variabel yang ada diteliti dan diamati oleh peneliti. Pada umumnya, peneliti menginginkan untuk memiliki subyek penelitian yang cukup banyak agar data yang diperoleh cukup banyak pula, Namun karena berbagai keterbatasan maka peneliti membatasi besarnya subjek penelitian. Oleh karena itu peneliti menentukan sampel penelitian,

\section{Populasi.}

Populasi

keseluruhan

penelitian.

penelitian ini adalah siswa kelas VIII MTs Negeri Sleman Kota. Alasan dipilinnya siswa kelas VIII sebagai subjek penelitian adalah karena puncak pelanggaran tata tertib ada di kelas VIII, sedangkan bila memilih kelas VII kondisi siswa kelas VII masih penyesuaian antara belajar di sekolalah dasar dengan belajar di sekolah menengah, sehinngga siswa kelas VII masih relatif tertib. Bila mengambil kelas IX bisa dipastikan penelitian akan mengganggu siswa dalam persiapan UNBK.

\section{Sampel.}

Teknik yang digunakan dalam menentukan sampel penelitian ini adalah cluster proposional random sampling yaitu teknik random sampling yang digunakan karena populasi tidak terdiri dari individuindividu, melainkan terdiri dari kelompok-kelompok individu atau cluster, dengan beberapa subpopulasi yang tidak sama jumlahnya.

Setelah

dilakukan sampling terpilihlah 30 subjek sebagai sempel penelitian ini. Sisanya sebagian dimanfatkan untuk tes ujicoba instrumen. Jumlah ini dirasa cukup mengingat penelitian eksperimen tidak memerlukan jumlah sempel yang cukup besar. 
operasionalisasi variable-variabel penelitian

\section{Definisi Konseptual Variable}

1. Bimbingan konseling kelompok adalah upaya bantuan kepada individu dalam suasana kelompok yang bersifat pemecahan masalah, dan diarahkan kepada pemberian kemudahan dalam rangka perkembangan dan pertumbuhannya.

2. Teknik Client Centered Therapy adalah teknik konseling dimana yang paling berperan adalah klien sendiri, klien dibiarkan untuk menemukan solusi mereka sendiri terhadap masalah yang tengah mereka hadapi.

3. Ketaatan Tata Terib Sekolah adalah kesediaan mematuhi ketentuan berupa peraturanperaturan mengenahi kehidupan sekolah sehari-hari.

\section{Definisi Operasional Variable}

1. Ketaatan terhadap tata tertib Sekolah adalah besarnya perolehan skor total peserta didik dalam menjawab seluruh item-item dalam angket instrument penelitian terkait ketaatan terhadap tata tertib sekolah.

2. Aktifitas ketaatan tata tertib sekolah adalah besarnya perolehan skor total peserta didik yang diperoleh dari pengamatan atau observasi sesuai item-item lembar observasi penelitian terkait seluruh aktifitas ketaatan terhadap tata tertib sekolah.

\section{Teknik Pengumpulan Data} 1. Angket

Angket yang digunakan

dalam penelitian ini menggunakan skala beringkat. Data yang diperoleh berupa skor dari variabel tataterib sekolah. Masing-masing kompetensi dasar harus memeiliki wakil minimal 2 butir soal. Jika kompetensi dasar hanya berjumlah satu soal dikhawatirkan setelah diuji validitas butir soal ternyata soal gugur, maka kompetensi dasar terebut tidak memiliki perwakilan soal.

2. Pedoman Observasi

Untuk mengamati proses konseling kelompok dengan teknik client centered therapy yang berlangsung dengan seksama serta memantau perkembangan siswa dari waktu ke waktu, maka menggunakan lembar instrument observasi. Observasi yang dilakukan yaitu 2 minggu sebelum layanan dan 2 minggu setelah layanan. Peneliti akan membandingkan hasil observasi dari setiap pertemuan dan melihat peningkatannya. 
Sebelum suatu instrument digunakan untuk mengambil data terlebih dahulu perlu dilakukan uji coba untuk mengetahui validitas dan reliabilitas alat ukur tersebut.

\section{Validitas Instrumen}

Validitas

yang digunakan adalah content validity (validitas isi) dan validitas konstruk.

\section{a. Validitas Isi}

Validitas

berkenaan

kesahihan

mengukur tujuan atau indikator layanan yang dirumuskan sesuai dengan materi layanan yang diberikan kepada peserta didik. Validitas isi dalam penelitian ini berkaitan dengan instrument yang digunakan untuk menilai layanan bimbingan konseling kelompok dengan teknik client centered therapy dalam meningkatkan ketaatan terhadab tata tertib sekolah dengan menggunakan skala sikap terhadap tata tertib sekolah. Langkahlangkah yang digunakan dalam pengujian validitas isi adalah (1) menyusun butir-butir instrument berdasarkan indikator untuk konstruk sikap terhadap tata tertib sekolah, konsultasi dengan ahli, untuk memeriksa relevansi isi instrument dengan variable yang ditentukan, dan (3) uji coba lapangan.

\section{b. Validitas Konstruk}

Dalam penelitian ini standar yang digunakan untuk menentukan valid atau tidak nya butir instrumen penelitian adalah lebih dari 0,3. Untuk menguji validitas butir maka skor-skor yang ada butir yang dimaksud dikorelasikan dengan skor total. Skor butir dipandang sebagai nilai $X$, dan skor total dipandang sebagai nilai Y. Kesejajaran ini dapat diartikan dengan korelasi, sehingga untuk mengetahui validitas item digunakan rumus korelasi.

Hasil analisis dengan metode pearson product moment menggunakan SPSS 10

Tabel 2. Hasil Uji Validitas Instrumen Skala Sikap 
Terhadap Ketaatan Tata Tertib Sekolah dengan SPSS 10

\begin{tabular}{|c|c|c|}
\hline Angket Skala Sikap & Nilai r Total & Keterangan \\
\hline Butir no. 1 & 0,603 & Valid \\
\hline Butir no. & 0,519 & Valid \\
\hline Butir no. 3 & 0,664 & Valid \\
\hline Butir no. 4 & 0,665 & Valid \\
\hline Butir no.5 & 0,757 & Valid \\
\hline Butir no. 6 & 0,640 & Valid \\
\hline Butir no.7 & 0,427 & Valid \\
\hline Butir no.8 & 0,802 & Valid \\
\hline Butir no. 9 & 0,548 & Valid \\
\hline Butir no. 10 & 0,431 & Valid \\
\hline Butir no. 11 & 0,439 & Valid \\
\hline Butir no.12 & 0,554 & Valid \\
\hline Butir no.13 & 0,717 & Valid \\
\hline Butir no.14 & 0,532 & Valid \\
\hline Butir no.15 & 0,394 & Valid \\
\hline Butir no.16 & 0,596 & Valid \\
\hline Butir no. 17 & 0,526 & Valid \\
\hline Butir no.18 & 0,498 & Valid \\
\hline Butir no.19 & 0,546 & Valid \\
\hline Butir no.20 & 0,573 & Valid \\
\hline
\end{tabular}

Koefisien korelasi yang telah didapat tersebut selanjutnya dibandingkan dengan $r$ tabel dengan taraf signifikansi $95 \%$. Dari data $r$ tabel untuk taraf signifikansi $95 \%$ dan $\mathrm{N}=30$ adalah sebesar 0,361. Dengan demikian maka dapat diputuskan bahwa 20 butir angket skala bertingkat mengenahi ketaatan terhadap tatatertib sekolah dinyatakan valid semua. Ke dua puluh butir tersebut selanjutnya digunakan untuk menjaring data penelitian.

\section{Reliabilitas Instrumen}

Tingkat

instrumen

berdasarkan reliabilitas

ditentukan

besarnya koefisien reliabilitas yang dimiliki. Semakin tinggi koefisien reliabilitas, semakin tinggi pula reliabilitas instrumen tersebut. Reliabilitas tes dihitung dengan rumus Cronbach Alpha. Koefisien alpha minimal yang diterima sebesr 0,7. Pengujian ini dilakukan terhadap butir-butir pertanyaan yang telah dinyatakan valid. Pengujian ini menggunakan alat bantu komputer dengan program SPSS 10. 
Tabel 3. Hasil Uji Reliabilitas Instrumen dengan SPSS 10

\begin{tabular}{|l|c|c|}
\hline \multicolumn{1}{|c|}{ Variabel } & Nilai & Keterangan \\
\hline $\begin{array}{l}\text { Ketaatan Terhadap Tata Tertib } \\
\text { Sekolah }\end{array}$ & 0,912 & Reliable \\
\hline
\end{tabular}

Instrumen yang sudah dinyatakan valid, setelah dilakukan uji reliabilitas dengan hasil 0,912, angka ini lebih besar dari $r$ tabel yaitu 0,7 sehingga instrumen ketaatan terhadap tatatertib sekolah dapat dinyatakan reliabel.

\section{Teknik Analisa Data}

\section{Uji Persyaratan Analisis}

Uji persyaratan analisis yang digunakan dalam penelitian ini meliputi uji normalitas dan uji homoginitas. Adapun langkah-langkah uji persyaratan dalam penelitian ini sebagai berikut :

a. Uji normalitas dilakukan menggunakn rumus Kolmogorov Smirnov dengan program SPSS 10. Data dikatakan berdistribusi normal apabila nilai $p>0,005$.

b. Uji homoginitas dilakukan untuk mengetahui kesamaan variansi, atau untuk menguji bahwa data yang diperoleh berasal dari populasi yang homogen.

2. Analisa Data dan Uji Hipotesis
Analisis data dalam penelitian ini dilakukan setelah data terkumpul dan selanjutnya hasil analisis digunakan untuk mengetahui signifikansi perbedaan antara sebelum dan sesudah layanan. Bila mana perlakuan konseling kelompok dengan teknik client centered therapy bersifat efektif, maka hasil sesudah layanan meningkat lebih dibanding sebelum layanan, sehingga setelah layanan (postes) ditemukan perbedaan yang signifikan. Teknik analisis yang digunakan dalam penelitian ini adalah uji t. Dalaam kegiatan analisis ini peneliti memakai aplikasi SPSS 10 dengan menggunakan aplikasi Paired t-test untuk pre test and pos test design tanpa kelompok kontrol.

Pengujian hipotesis dilakukan dengan cara sebagai berikut :

a. Distribusi pengujian menggunakan independen sampel $t$ test untuk mengetahui 
apakah ada perbedaan hasil layanan konseling kelompok dengan tehnik client centerd therapy yang signifikan antara sebelum dan sesudah treatment.

b. Keputusan

diambil dengan cara membandingkan nilai $t_{\text {hitumg }}$ dengan $t_{\text {tabel }}$ Jika $t_{\text {hitung }}<t$ tabel maka keputusan menerima $\mathrm{H}_{\text {o }}$. sebaliknya, jika $t_{\text {hitung }}>\mathrm{t}$ tabel maka keputusan tidak menerima $\mathrm{H}_{\mathrm{o}}$.

c. Kesimpulan ditarik berdasarakn keputusan yang diambil. Jika keputusan menerima $\mathrm{H}_{\mathrm{o}}$, kesimpulannya adalah tidak ada perbedaan hasil layanan yang signifikan antara sesudah dan sebelum treatment. Sebaliknya, jika keputusan menolak $\mathrm{H}_{\mathrm{o}}$ dan menerima $\mathrm{H}_{\mathrm{a}}$ kesimpulanya terdapat perbedaan hasil layanan yang signifikan antara sebelum dan sesudah treatment.

\section{HASIL PENELITIAN DAN PEMBAHASAN}

Penelitian mixed method (campuran) yang mengambil subjek siswa MTs N 4 Sleman ini mengetahui perbedaan antara sebelum dan sesudah layanan konseling kelompok dengan teknik client centered therapy dalam meningkatkan ketaatan terhadap tatatertib sekolah. Indikatornya adalah "ada tidaknya perbedaan sikap yang signifikan dalam peningkatan ketaatan terhadap tatatertib sekolah antara sebelum dan sesudah subjek memperoleh layanan konseling kelompok dengan teknik client centered therapy “. Yang dimaksud sikap dalam penelitian ini adalah sikap siswa terhadap ketaatan tatatertib sekolah.

\section{Hasil Penelitian}

Dalam

penelitian

eksperimental ini peneliti melakukan pre test sebelum subjek mendapat layanan serta post test terhadap subjek sesudah mendapat layanana berupa layanan konseling kelompok dengan teknik client centered therapy. Materi pre test dan postes mencakup tes sikap terhadap ketaatan tata tertib sekolah. Untuk lebih jelasnya akan kami sampaikan hasil penelitian mulai dari gambara responden sebelum layanan, gambaran responden sesudah layanan dan pembahasan. 
Gambaran

Responden

\section{Sebelum Layanan}

1. Data hasil pretes sikap terhadap ketaatan tatatertib sekolah.

Data mengenahi sikap dalam penelitian ini berfokus kepada ketaatan terhadap tata tertib sekolah. Pengumpulan data pre test yang telah dilakukan menghasilkan data berupa skor.

Instrumen

pengumpulan data berupa skala likert yang digunakan peneliti untuk memperolah data pretes mengenahi sikap terhadap ketaatan tata tertib sekolah berhasil menjaring data berupa skor. Selanjutnya skor tersebut dianalisa menggunakan SPSS. 10. Hasilnya seperti tertera dalam tabel berikut:

\section{Tabel 4. Variabilitas Pre Test Skor Sikap Terhadap Ketaatatan Tata Tertib Sekolah}

\begin{tabular}{|c|c|}
\hline & Skor pretes sikap \\
\hline $\mathrm{N}$ & 30 \\
\hline Mean & 56,27 \\
\hline Median & 56,00 \\
\hline Mode & 56 \\
\hline Minimum & 48 \\
\hline Maximum & 65 \\
\hline Sum & 1688 \\
\hline
\end{tabular}

Untuk memperoleh menyajikan data secara gambaran yang lebih jelas, visual dalam bentuk grafik. berikut ini penulis

\section{Grafik 1. Skor Pre Tets Sikap Terhadap Ketaatan Tata Tertib} Sekolah 


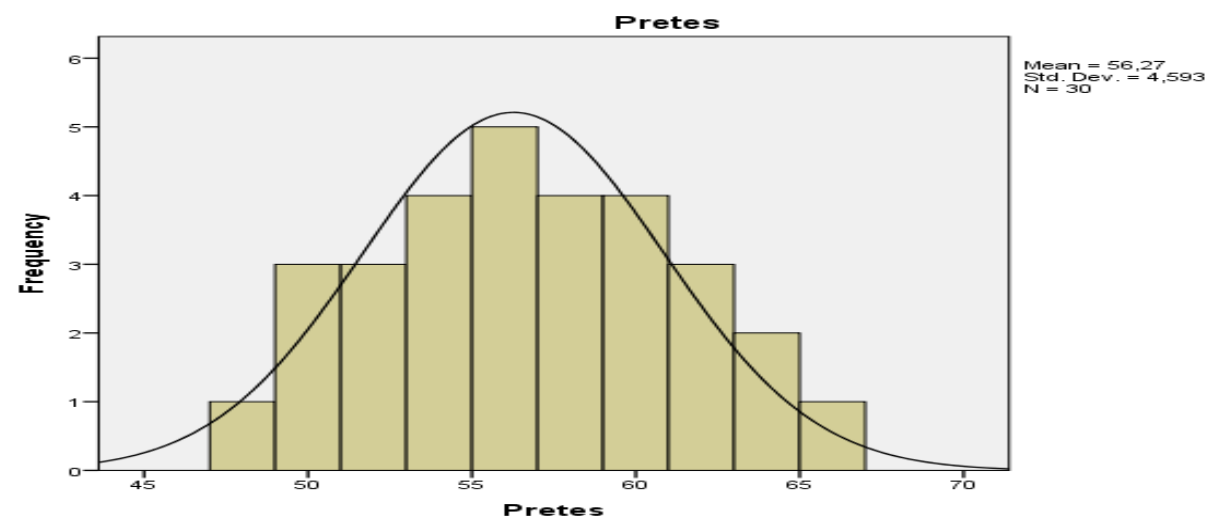

2. Deskripsi Data Pre Test Sikap Ketaatan Tata Tertib Sekolah.

3. Data hasil pre test di atas menunjukkan nilai mean skor pre test sikap terhadap tatatertib sekolah sebesar 56,27 nilai rerata ini selanjutnya dibandingkan dengan tabel berikut :

\section{Tabel 5. Tolok Ukur Sikap terhadap Ketaatan} Tata Tertib Sekolah

5.

\begin{tabular}{|c|c|}
\hline $\begin{array}{c}\text { 6. Interval } \\
\text { Skor }\end{array}$ & $\begin{array}{c}\text { 7. Tingkat } \\
\text { Sikap }\end{array}$ \\
\hline $8.84-100$ & $\begin{array}{c}\text { 9. Sangat } \\
\text { Tinggi }\end{array}$ \\
\hline $10.68-83$ & 11. Tinggi \\
\hline $12.52-67$ & 13. Sedang \\
\hline $14.36-51$ & 15. Rendah \\
\hline
\end{tabular}

16.

17. Berdasarkan ketentuan dalam tabel, maka tingkat sikap siswa terhadap ketaatan tata tertib sekolah masih dalam kategori sedang. Hal ini masih cukup memprihatinkan, apalagi mengingat madrakah merupakan pendidikan berbasic islam. Untuk itu ketaatan terhadap tata tertib sekolah penting untuk ditingkatkan.
18.

ata Hasil Observasi Sebelum Layanan

19. Berdasarkan data yang diperoleh dalam observasi sebelum responden mendapatkan layanan konseling kelompok dengan teknik client centered therapy menunjukkan bahwa perilaku responden dalam mentaati tatatertib sekolah masih rendah. 
20.

\section{Gambaran \\ Responden \\ Sesudah \\ Layanan.}

1. Data Hasil Post Test Sikap

Ketaatan

Sekolah.
Terhadap

Tatatertib
22. Setelah responden diberikan layanan konseling kelompok dengan teknik client centered therapy kemudian di berikan post test, dari postes berhasil menjaring data sebagai

berikut :

23. Tabel 6. Rangkuman Hasil Uji Normalitas Sebaran Skor One-Sample

\section{Kolmogorov-Smirnov Test \\ 24 Kolmogorov-Smirnov Test}

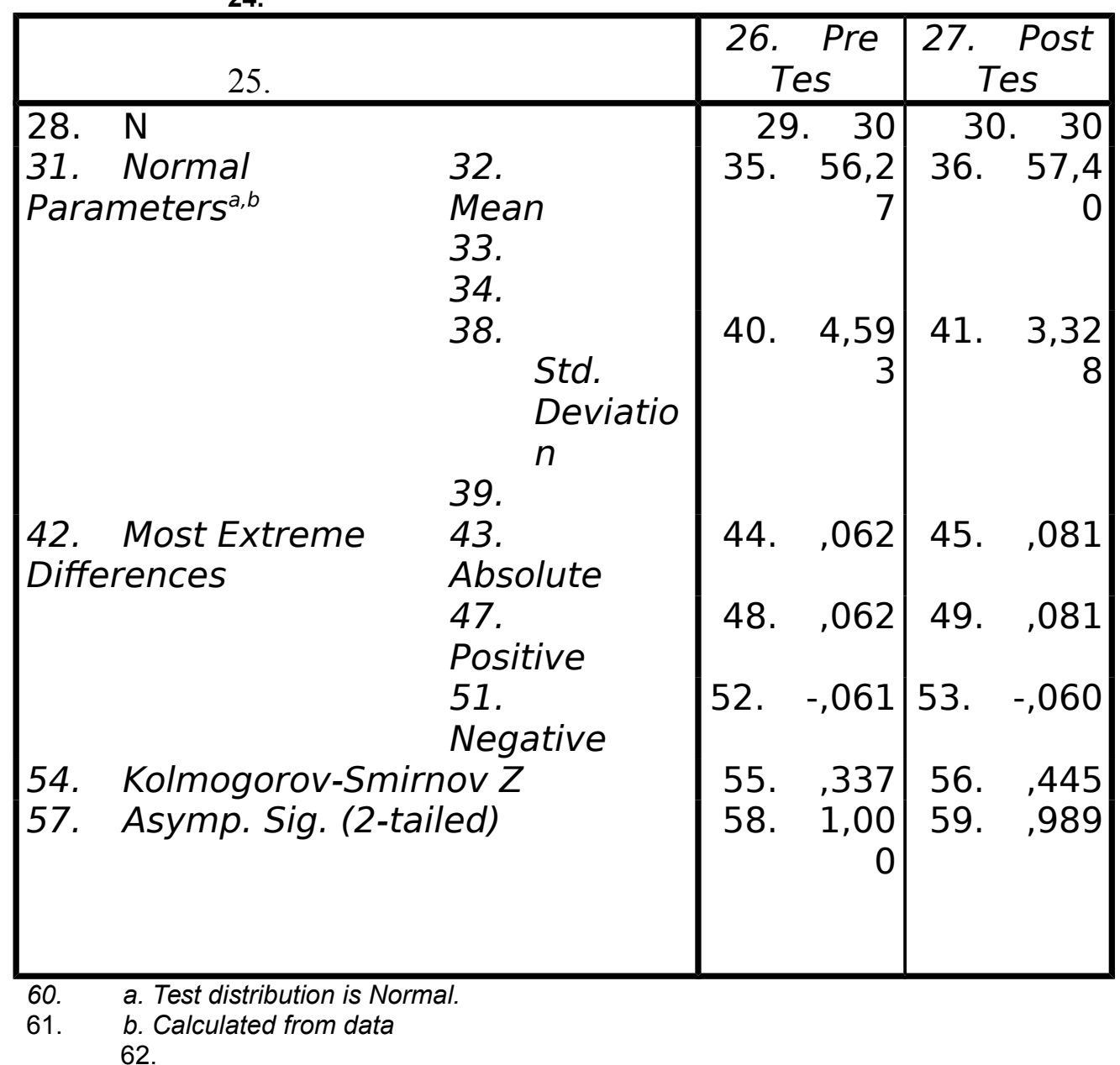

63. Berdasar hasil uji normalitas sebaran dengan teknik Kolmogorov-Smirnov dapat disimpulkan bahwa sebaran skor pre test maupun post test dari variabel sikap hasilnya normal.

64.

1. Uji Homogenitas Sampel 65. Uji homoginitas sampel dilakukan untuk 
mengetahui apakah skor variabel yang diteliti menunjukkan homogenitas. Hasil uji homogenitas 66.

\section{7.} Test Sikap Terhadap Ketaatatan Tata Tertib 68.

\begin{tabular}{|r|r|}
\hline 69. & $\begin{array}{r}\text { 70. } \\
\text { Skor } \\
\text { Po } \\
\text { st } \\
\text { es } \\
\text { Sik } \\
\text { ap }\end{array}$ \\
& 72.30 \\
\hline & 74.57 \\
& 40 \\
\hline $71 . \mathrm{N}$ & 76.57 \\
73. Mea \\
$n$ & 00 \\
\hline 75. Med & 78.57 \\
ian & \\
\hline 77. Mod & 80.51 \\
$e$ & \\
\hline 79. Mini \\
mu \\
$m$ & 82.64 \\
\hline 81. Max & \\
imu & \\
$m$ & 22 \\
\hline 83. Sum & \\
& \\
\hline & \\
\hline
\end{tabular}

85.

86. ntuk memperoleh gambaran yang lebih jelas, berikut ini

secara visual dalam bentuk grafik.

87. menggunakan teknik anova dengan menggunakan SPSS. 10 menunjukkan hasil sebagai berikut.
Sekolah

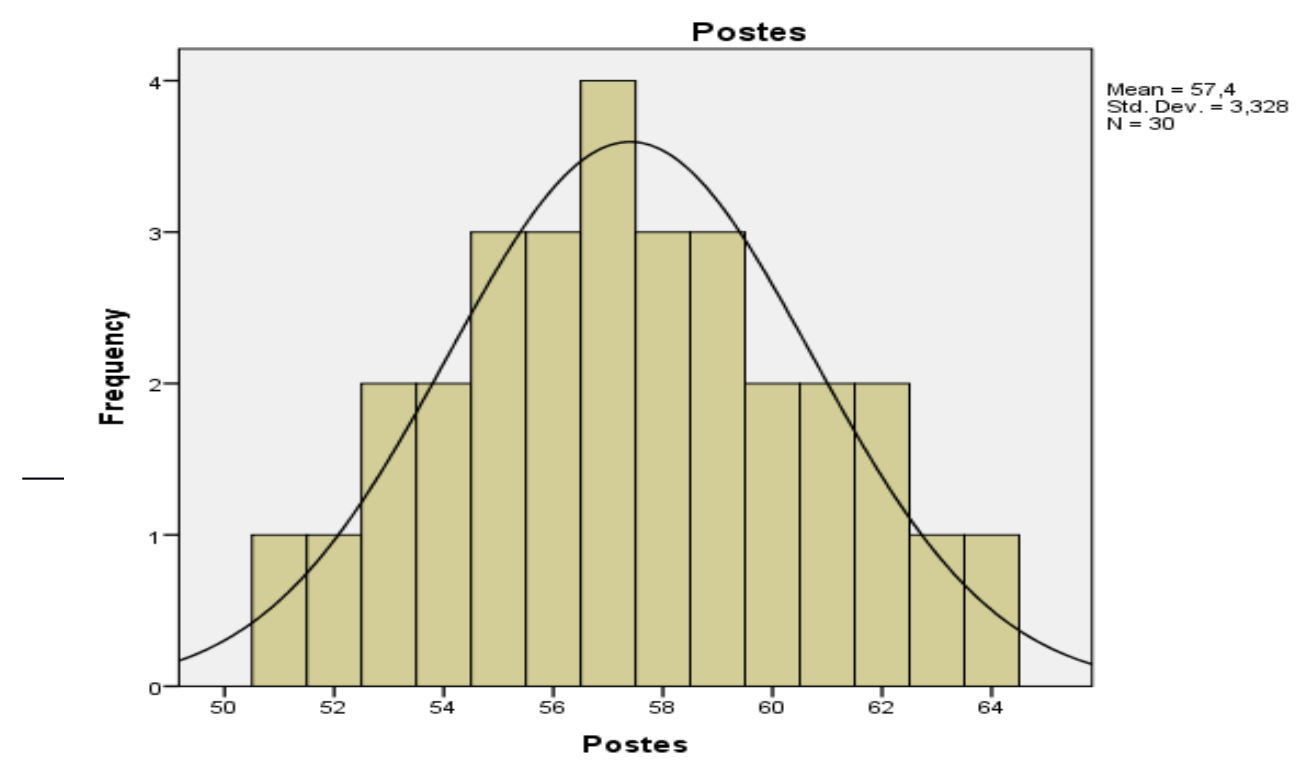



95.
96.
97.
98.
99.
100.
101.
102.
103.
104.
105.

2. Deskripsi Data Post Test Sikap Terhadap Tata Tertib Sekolah.

3. Data hasil postes

di atas menunjukkan nilai mean skor postes sikap terhadap tatatertib sekolah sebesar 57,4 nilai rerata ini setelah dibandingkan dengan tabel menunjukkan kategori sedang, namun mengalami peningkatan.

4. Data Hasil Observasi Sesudah Layanan

5. Berdasarkan data dari hasil observasi sesudah layanan, menunjukkan adanya peningkatan ketaatan responden terhadap tata tertib sekolah setelah responden mendapatkan konseling kelompok dengan teknik client centered therapy.

6. Uji Perbedaan Antara Sebelum dan Sesudah Layanan

a. Uji Prasyarat Analisis
7. Sebelum

proses analisis data, terlebih dahulu harus dilakukan uji prasyarat analisis data. Uji ini dilakukan untuk mengetahui normalitas sebaran dan homogenitas sampel. Setelah uji prasyarat ini dilakukan tuntas, barulah analisis terhadap data penelitian dilakukan. Berikut ini diuraikan hasil uji normalitas sebaran dan uji homoginitas sampel menggunakan bantuan statistik SPSS 10.

b. Uji Normalitas 
8.

normalitas

sebaran bertujuan

untuk mengetahui

apakah skor suatu

variabel

berdistribusi

normal atau tidak.

Dalam penelitian

ini variabel yang

diuji normalitas

sebarannya adalah

skor pre test yang

mencakup pre test

sikap dan skor

9.
Teknik statistik

yang digunakan

dalam menguji

normalitas dalam

penelitian ini

adalah teknik

Kolmogorov-

Smirnov. Setelah

dilakukan

penghitungan

menggunakan

SPSS.10, maka

hasil

penghitungannya

adalah sebagai

berikut.

10.

11. Tabel 7. Rangkuman Hasil Uji Normalitas Sebaran Skor One-

Sample Kolmogorov-Smirnov Test

12.

13.

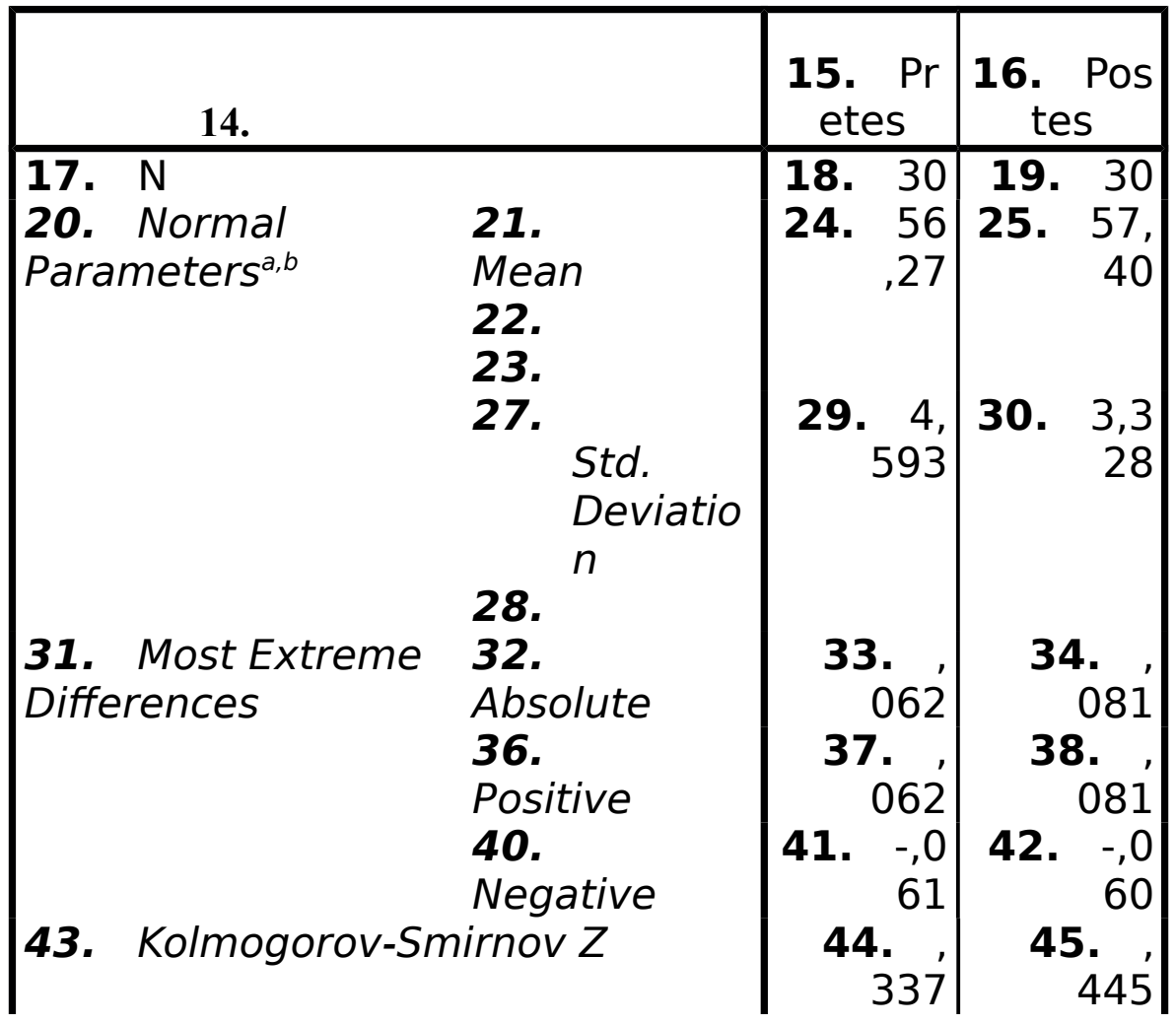




\begin{tabular}{|l|r|r|}
\hline 46. Asymp. Sig. (2-tailed) & 47. 1, & 48. \\
& 000 & 989 \\
& & \\
\hline
\end{tabular}

49. a. Test distribution is Normal.

50. b. Calculated from data

51.

52. Berdasar hasil uji normalitas sebaran dengan teknik

Kolmogorov-Smirnov

dapat disimpulkan

bahwa sebaran skor pre test maupun post test dari variabel sikap hasilnya normal.

c. Uji

Homogenitas

Sampel

53. Uji

homoginitas sampel

54.

55.

Tabel 8. Hasil Uji Homogenitas Sampel Variabel Sikap TerhadapKetaatan Tata Tertib Sekolah

56.

dilakukan

untuk mengetahui apakah skor variabel yang diteliti menunjukkan

homogenitas. Hasil uji homogenitas menggunakan

teknik anova dengan menggunakan SPSS. 10 menunjukkan hasil sebagai berikut.

1. Test of Homogeneity of Variances

2. Pretes

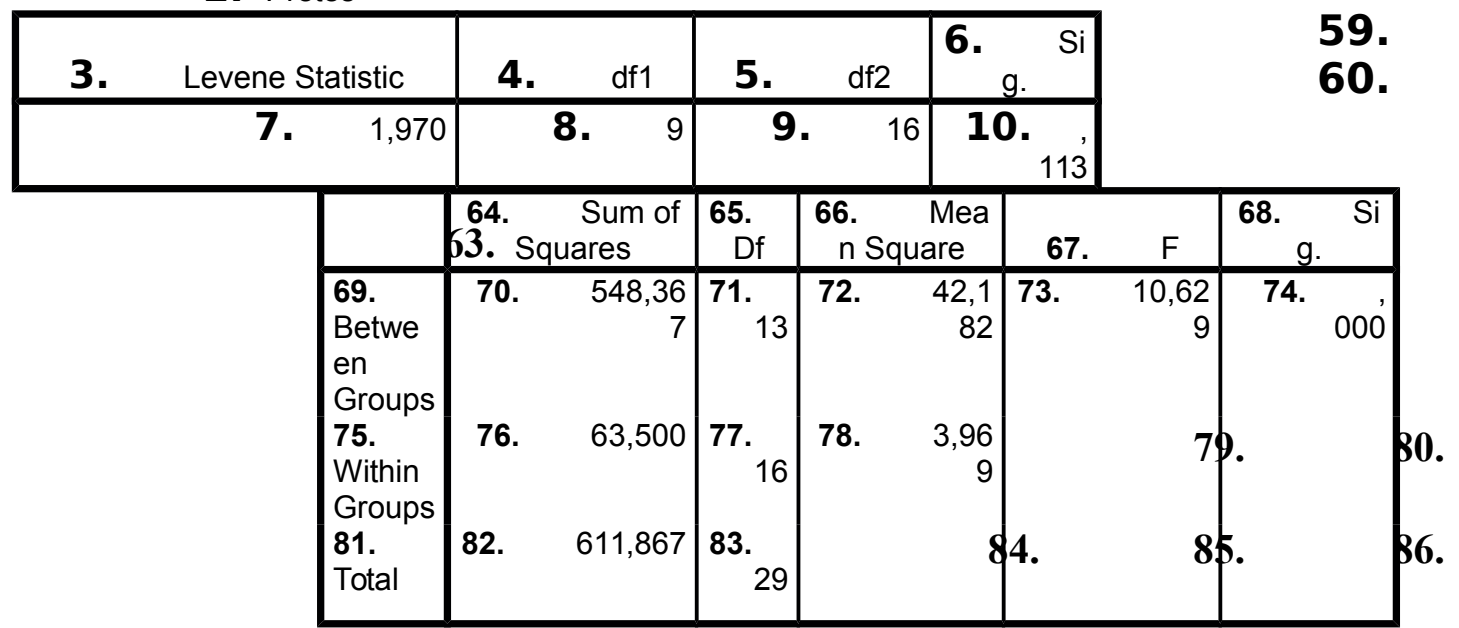

87.

88. 
ditunjukkan dengan

hasil uji homoginitas diatas standar tabel 0,005 yaitu 0,113 .

89.

d. Uji

\section{Penelitian}

Hipotesis

90.

alam

penelitian

eksperimental model

one group pre test- post test ini dilakukan

91.

92.

Tabel 9. Hasil Uji-t

Menggunakan SPSS.10

93.

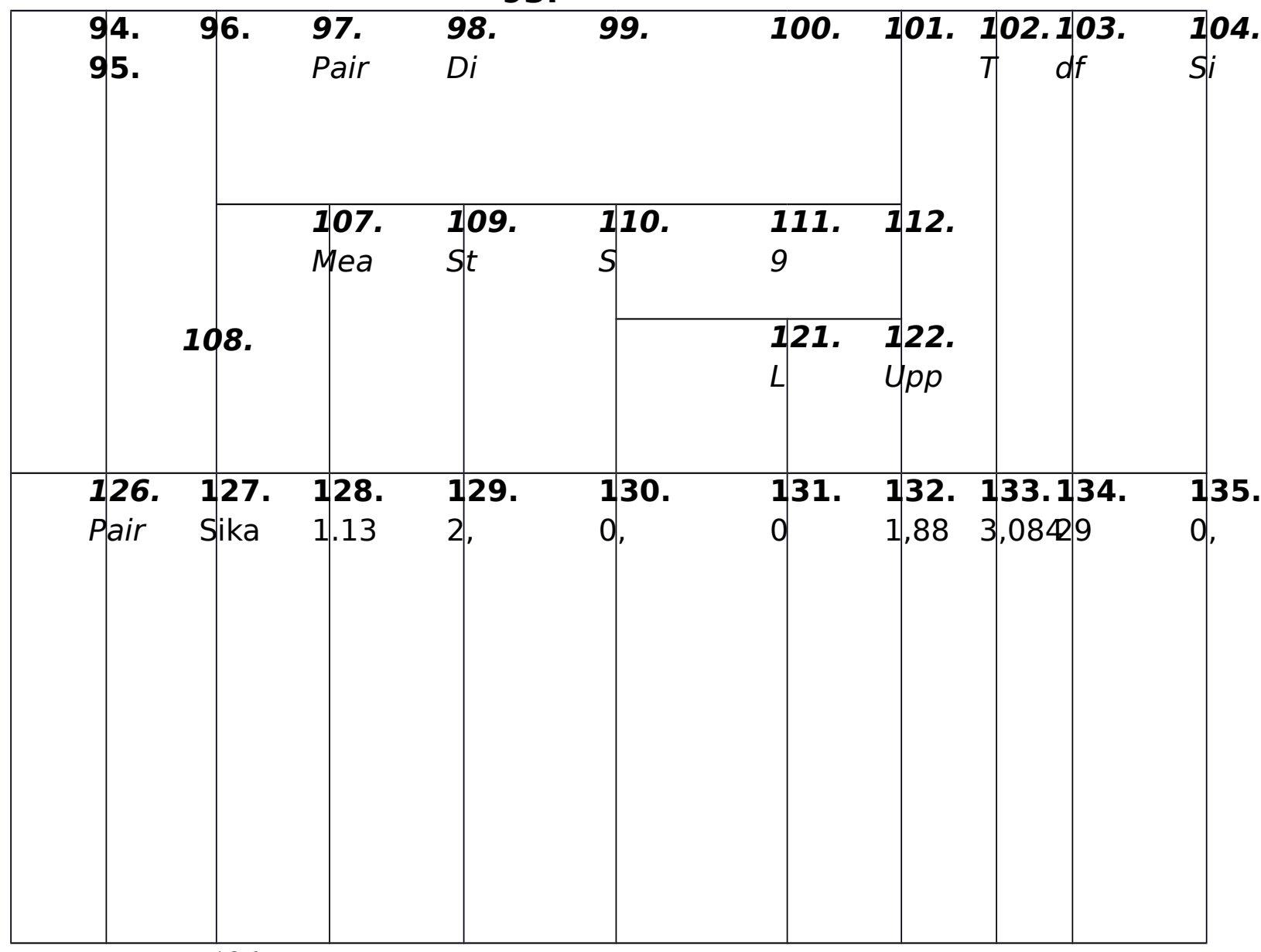

136.

analisis komparasi (uji beda) dengan teknik ujit menggunakan program SPSS. 10. Uji statistik ini untuk mengetahui ada tidaknya perbedaan yang signifikan antara sebelum dan sesudah subjek dikenai layanan. Hasil uji-t terlihat dalam tabel di bawah ini. 
ketaatan terhadap tata tertib sekolah. Nilai ini jelas signifikan karena lebih besar dengan nilai $t$ tabel yang hanya sebesar 0,683 untuk interval kepercayaan yang sama. Jadi, perbedaan skor pretes dan postes tersebut signifikan.

138.

139.

\section{embahasan}

140.

enelitian eksperimental dengan subjek 30 siswa kelas VIII MTs N 4 Sleman ini telah berhasil menjaring data yang telah dideskripsikan. Data tersebut selanjutnya diolah dan dianalisis. Setelah menempuh langkah analisis, maka untuk mendapatkan pemahaman secara tuntas terhadap hasil penelitian maka selanjutnya penulis akan melakukan pembahasan terhadap hasil penelitian tersebut.

141.

1. Pelaksanaan

Konseling

Kelompok Dengan Teknik Client

Centered Therapy Dalam

Meningkatkan Ketaatan

Terhadap Tata Tertib Sekolah.

142. Sebelum pelaksanaan

layanan konseling kelompok

dengan teknik client centered terlebih dahulu peneliti membuat rencana pelaksanaan layanan atau satuan layanan atau sering disingkat RPL( RPL dapat dilihat pada halaman lampiran). konseling kelompok dengan teknik client centered therapy, dalam proses ini dibagi menjadi empat tahap, berikut penjelasan masingmasing tahapan:

143.

\section{Pembentukan}

144. Tahap pembentukan atau tahap awal sebagai tahap persiapan diselenggarakan dalam rangka pembentukan kelompok sampai mengumpulkan peserta yang siap melaksanakan kegiatan kelompok. Konselor melakukan upaya untuk menumbuhkan minat terbentuknya kelompok.

145.

\section{TAHAP II : Tahap Transisi}

146.

Tahap transisi (peralihan) merupakan masa setelah proses pembentukan atau awal konseling dan sebelum masa bekerja atau konseling. Transisi mulai dengan masa badai, yang mana anggota mulai bersaing dengan yang lain dalam kelompok untuk mendapatkan tempat, kekuasaan dalam kelompok. Maka badai adalah masa munculnya perasaanperasaan kecemasan, pertentangan, pertahanan, ketegangan, konflik, konfrontasi, transferensi. Selama masa ini, suasana kelompok diambang ketegangan dan ketidak seimbangan. Dalam keadaan ini banyak anggota yang merasa tertekan atau resah dalam pelayanan konseling dan tingkah 
laku mereka menjadi tidak sebagaimana mestinya.

147. Pada saat ini dibutuhkan keterampilan konselor dalam beberapa hal, yaitu kepekaan waktu, kemampuan melihat perilaku anggota, dan mengenal emosi di dalam kelompok.

148. TAHAP III : Tahap Kegiatan.

149. Tahap ini disebut juga tahap bekerja, tahap penampilan, tahap tindakan yang merupakan inti kegiatan kelompok, aka aspekaspek tersebut perlu mendapat perhatian yang seksama dari konselor. Kelangsungan kegiatan kelompok dalam tahap ini amat tergantung pada hasil dari dua tahap sebelumnya. Tahap ini merupakan tahap kehidupan yang sebenarnya dari konseling kelompok, yaitu para anggota kelompok memusatkan perhatian terhadap tujuan yang akan dicapai, mempelajari materi-materi baru, mendiskusikan topik, menyelesaikan tugas, dan melakukan kegiatan terapeutik. Tahap ini sering dianggap sebagai tahap yang paling produktif dalam perkembangan kelompok dan ditandai dengan keadaan konstruktif dan pencapaian hasil. Para anggota kelompok memperoleh keuntungan atau pengaruh-pengaruh positif dari kelompok, dan merupakan saatnya anggota kelompok memutuskan seberapa besar mereka mau terlibat dalam kegiatan kelompok. 150. TAHAP IV : Tahap Pengakhiran ( Terminasi ).

151. Kegiatan anggota yang paling penting dalam tahap pengakhiran atau penghentian adalah untuk merefleksikan pengalaman mereka di masa lalu, untuk memproses kenangan, untuk mengevaluasi apa yang telah mereka peajari, untuk menyatakan perasaan yang bertentangan, dan untuk berhubungan dalam membuat keputusan kognitif. Melalui pertisipasi mereka dalam kegiatan, anggota kelompok dibantu untuk mmenggabungkan dan menggunakan informasi yang berasal dari pengalaman kelompok di luar situasi yang ada. Mereka dibantu untuk menggeneralisasikan pembelajaran dari sebuah situasi ke situasi lain.

2. Deskripsi Hasil Layanan Konseling Kelompok Dengan Teknik Client Centered Therapy Dalm Meningkatkan Ketaatan Terhadap Tata Tertib Sekolah.

152. Dengan hasil uji-t membuktikan bahwa ketaatan terhadap tatatertib sekolah mampu ditingkatkan melalui layanan konseling kelompok dengan teknik client centered therapy. Hal ini ditunjukkan oleh hasil uji-t yang menunjukkan taraf signifikansi yang tinggi yaitu $\mathrm{t}=3,084$. Sementara itu nilai $\mathrm{t}$ tabel untuk $\mathrm{N}$ $=30$ dengan taraf signifikansi 95\% hanya sebesar 0,683. Dengan 
demikian penulis yakin bila layanan konseling kelompok dengan teknik client centered therapy dilakuakan secara berkesinambungan akan membuahkan hasil optimal dalam menjawab permasalahan yang ada. 153. Dengan demikian Ho yang berbunyi tidak ada pebedaan hasil antara sebelum mendapatkan layanan konseling kelompok dengan teknik client centered therapy dan sesudah mendapatkan layanan konseling kelompok dengan teknik client centered therapy ditolak. Sedangkan $\mathrm{Ha}$ yang berbunyi ada pebedaan hasil antara sebelum mendapatkan perlakuan konseling kelompok dengan teknik client centered therapy dan sesudah mendapatkan perlakuan konseling kelompok dengan teknik client centered therapy diterima.

154. Setelah melihat hasil temuan tadi penulis yakin bahwa permasalahan rendahnya ketaatan terhadap tatatertib sekolah dapat tertangani dengan baik dengan menggunakan layanan konseling kelompok dengan teknik client centered therapy. Dengan demikian kecemasan terhadap pelanggaran tatatertib sekolah bisa diminimalisir atau bahkan dihilangkan.

155. Berdasarkan data yang diperoleh dari pre test, post test dan didukung oleh hasil observasi, kemudian dilakukan analisa hasilnya menunjukkan bahwa teori dari PPPPTK Penjas dan BK yang mengatakan bahwa "konseling kelompok merupakan cara yang efektif dan efisien untuk mendukung dan membantu siswa dalam mencegah dan memecahkan masalah" terbukti. Sedangkan teori Rogers tentang asumsi dasar client centerd therapy yang mengemukakan bahwa Individu memiliki kapasitas untuk membimbing, mengatur, mengarahkan, dan mengendalikan dirinya sendiri apabila ia diberikan kondisi tertentu yang mendukung. Juga terbukti dengan hasil penelitian yang menunjukkan signifikansi yang tinggi.

3. Deskripsi Hasil Observasi

156. Berdasarkan data dari hasil observasi sebelum pre test dan sesudah post test, dapat di tarik kesimpulan bahwa, ada pengaruh yang positif antara sebelum diberikan layanan konseling kelompok dengan teknik client centered therapy dengan sesudah siswa mendapatkan layanan konseling kelompok dengan teknik clien centered therapy.

4. Faktor Pendukung dan Penghambat

157. Berdasarkan jalannya pelaksanaan penelitian dapat disampaikan faktor pendukung dan penghambat dari pelaksanaan penelitian dengan menggunakan layanan konseling kelompok dengan teknik client centered therapi dalam meningkatkan 
ketaatan terhadap tatatertib sekolah

a. Faktor Pendukung.

1) Faktor dari guru BK.

158. Ketrampilan

yang mendukung dari guru

BK dalam menerapkan layanan konseling kelompok dengan teknik client centered therapy, diantaranya adalah:

a) Ketrampilan dalam mengidentifikasi

faktor-faktor dari respon verbal

b) Ketrampilan memahami dasar interviu dalam proses menerima (attending), mendengarkan

(listening), dan mempengaruhi

(influencing), serta dampak potensial pada konseli untuk berubah.

c) Ketrampilan mengetahui dan menerapkan bagaimana dan kapan menggunakan konfrontasi.

d) Ketrampilan dalam mengetahui dan menerapkan ketrampilan interviu.

2) Faktor Pendukung dari Klien
a) Kesadaran untuk berubah.
b) Kesediaan dibantu.

c) Kesadaran

kemandirian

dalam menyelesaikan masalahnya sendiri.

\section{b. Faktor Penghambat}

1) Faktor dari guru $\mathrm{BK}$ 159. urangnya Ketrampilan yang dimiliki dari guru BK dalam menerapkan layanan konseling kelompok dengan teknik client centered therapy, diantaranya adalah:

a) Kurang trampil dalam mengidentifikasi faktor-faktor dari respon verbal.

b) Kurang trampil memahami dasar interviu dalam proses menerima (attending), mendengarkan

(listening), dan mempengaruhi

(influencing), serta dampak potensial pada konseli untuk berubah.

c) Kurang trampil mengetahui dan menerapkan bagaimana dan kapan menggunakan konfrontasi.

d) Kurang trampil dalam mengetahui dan menerapkan ketrampilan interviu.

2) Faktor Pendukung dari klien 
a) Tidak ada Kesadaran dari clien untuk berubah.

b) Klien tidak bersedia untuk dibantu.

c) Klien tidak ada Kesadaran atau kurangnya kemandirian dalam menyelesaikan masalahnya sendiri.

160.

161.

162.

\section{ESIMPULAN DAN SARAN}

163.

Penelitian

eksperimental yang bertujuan untuk mengetahui perbedaan antara sebelum dan sesudah mendapatkan perlakuan konseling kelompok dengan teknik client centered therapy dalam meningkatkan ketaatan terhadap tatatertib sekolah berhasil menjaring dan menganalisis data kuantitatif dan kualitatif dari sampel penelitian yang berjumlah 30 subjek.

164.

165.

K

esimpulan

166. Setelah menempuh prosedur penelitian yang telah direncanakan akhirnya penenlitian ini menghasilkan kesimpulan sebagai berikut :

1. Tingkat ketaatan siswa sebelum mendapatkan perlakuan layanan konseling kelompok dengan teknik client centered theraph nilai mean skor pretes sikap terhadap tata tertib sekolah sebesar 56,27 nilai rerata ini setelah dibandingkan dengan ketentuan dalam tabel masuk kategori sedang.

2. Tingkat ketaatan siswa sesudah mendapatkan perlakuan layanan konseling kelompok dengan teknik client centered theraph nilai mean skor pretes sikap terhadap tata tertib sekolah sebesar 57,4 nilai rerata ini mengalami peningkatan dengan sebelum mendapatkan perlakuan konseling kelompok dengan teknik client centered therapy meskipun setelah dibandingkan dengan ketentuan dalam tabel masih masuk kategori sedang.

3. Ada perbedaan tingkat ketaatan antara sebelum dan sesudah mendapatkan perlakuan layanan konseling kelompok dengan teknik client centered therapy. Hal ini ditunjukkan dengan hasil uji $\mathrm{t}$ yang menunjukkan taraf signifikansi yang tinggi yaitu $\mathrm{t}=$ 3,084 Sementara itu nilai tabel untuk $\mathrm{N}=30$ dengan taraf 
signifikansi $\quad 95 \% \quad$ sebesar 0,683.Dengan demikian Ho yang berbunyi tidak ada pebedaan hasil antara sebelum mendapatkan layanan konseling kelompok dengan teknik client centered therapy dan sesudah mendapatkan layanan konseling kelompok dengan teknik client centered therapy ditolak. Sedangkan $\mathrm{Ha}$ yang berbunyi ada pebedaan hasil antara sebelum mendapatkan perlakuan konseling kelompok dengan teknik client centered therapy dan sesudah mendapatkan perlakuan konseling kelompok dengan teknik client centered therapy diterima.

167. Hasil ini juga didukung dengan hasil observasi sebelum dan sesudah layanan konseling kelompok dengan teknik client centered therapy yang menunjukkan peningkatan ketaatan terhadab tata tertib sekolah yang signifikan.

168.

169.

170.

171.

aran

172. A gar penelitian ini menjadi lebih bermakna, berikut ini penulis menyampaikan beberapa saran kepada beberapa pihak :
1. Kepada Kepala Madrasah penulis menyarankan untuk menindak lanjuti temuan penelitian ini sebagai upaya meningkatkan ketaatan terhadap tatatertib sekolah di lingkungan Madrasyah.

2. Kepada Guru Bimbingan Konseling dapat menindak lanjuti hasil penelitian ini guna meningkatkan layanan terhadap anak asuhnya melalui konseling kelompok dengan teknik client centerd therapy.

3. Kepada Guru Bidang Studi dapat menindak lanjuti hasil penelitian ini sebagai dasar untuk engembangkan proses belajar mengajar melalui layanan konseling kelompok dengan teknik client centered therapy.

173.

Demikian saran yang dapat penulis sampaikan, semoga memperoleh respon positif.

174.

175. DAFTAR

\section{PUSTAKA}

176. Dokumen Catatan Pelanggaran Tata Tertib. 2016-2017. BK MTs Negeri Sleman Kota.

177.

178. Gerall Correy. 2003. Teori dan Praktik Konseling dan Psikoterapi. Bandung: PT.Refika Aditamma.

179.

180. Http://eko

13.wordpress.com/2011/04/14

Pendidikan Konseling Client Centered. 
181.

182. Nurul Zuriah. 2006. Metodologi Penelitian Sosial dan Pendidikan. Jakarta: PT. Bumi Aksara.hlm. 124.

183.

184. Prayitno dan Erman Audi. 1994. Dasar-Dasar Bimbingan dan Konseling, Jakata: Depdikbud.

185.

186. РРPРTK Penjas dan BK. 2014. Buku Panduan Bimbingan dan Konseling di Sekolah. Jakarta : PT.Binatama Cipta Pratama.

187.
188. Sayekti.1994. Pelaksanaan Konseling kelompok, Yogyakarta : Upaya Pelayanan Bimbingan Konseling. IKIP Yogyakarta.

189.

190. Suharsimi Arikunto.2007. Dasar -dasar Evaluasi Pendidikan. Jakarta : Bumi Aksara.

191.

192. Tim Dosen Jurusan Administrasi Pendidikan FIP IKIP Malang.1989.

193. 